\title{
Wheat responses to arbuscular mycorrhizal fungi in a highly calcareous soil differ from those of clover, and change with plant development and P supply
}

\author{
H.Y. Li ${ }^{1,2,4}$, Y.G. Zhu ${ }^{1,3}$, P. Marschner ${ }^{1}$, F.A. Smith ${ }^{1}$ \& S.E. Smith ${ }^{1}$ \\ ${ }^{1}$ Centre for Soil-Plant Interactions, Soil and Land Systems, School of Earth and Environmental Sciences, The \\ University of Adelaide, Waite Campus, 5005, South Australia, DP636, Australia. ${ }^{2}$ The Institute of Genetics \\ and Developmental Biology, Chinese Academy of Sciences, Research Centre for Agricultural Resources, \\ 050021, Shijiazhuang, China. ${ }^{3}$ Chinese Academy of Sciences, Research Centre for Eco-environmental Sci- \\ ences, 100085, Beijing, China. ${ }^{4}$ Corresponding author*
}

Received 18 January 2005. Accepted in revised form 9 May 2005

Key words: arbuscular mycorrhizal fungi, grain yield, growth response, phosphorus uptake

\begin{abstract}
We evaluated the roles of arbuscular mycorrhizal (AM) fungi in growth and phosphorus (P) nutrition of wheat (Triticum aestivum L.) in a highly calcareous soil and compared the responses of wheat with those of clover (Trifolium subterraneum L). In the first experiment wheat (cv. Brookton) was harvested at $6 \mathrm{wk}$. Colonisation by four AM fungi was low $(<20 \%)$. Clover was harvested at 8 wk. Colonisation varied with different fungi, with the highest value (52\%) obtained with Glomus intraradices. Although suffering from $\mathrm{P}$ deficiency, non-mycorrhizal (NM) wheat grew relatively well with no added P (P0) and application of P at $100 \mathrm{mg} \mathrm{kg}^{-1}$ (P100) increased the dry weight (DW). Shoot $\mathrm{P}$ concentrations increased with $\mathrm{P}$ application and there were positive effects of all AM fungi at P100. In contrast, NM clover grew very poorly at P0 and did not respond to $\mathrm{P}$ application. Clover responded positively to all AM fungi at both $\mathrm{P}$ levels, associated with increases in $\mathrm{P}$ uptake. In the second experiment colonisation by a single AM fungus (G. intraradices) of two wheat cultivars (Brookton and Krichauff) was well established at 6 wk ( $\sim 50 \%$ in P0 plants) and continued to increase up to maturity $(\sim 70 \%)$, but decreased greatly at both harvests as $\mathrm{P}$ supply was increased (up to $150 \mathrm{mg} \mathrm{P} \mathrm{kg}^{-1}$ : P150). Addition of $\mathrm{P}$ significantly increased plant growth, grain yield and $\mathrm{P}$ uptake irrespective of cultivar and harvest time, and the optimum soil P for grain yield was P100. In both cultivars, a growth depression in AM plants occurred at $6 \mathrm{wk}$ at all P levels, but disappeared at $19 \mathrm{wk}$ with added P. At P0, AM plants also produced lower grain yield (weight) per plant, but with higher P, AM plants produced higher grain yields than NM plants. There was a significant positive effect of AM on grain $\mathrm{P}$ concentration at $\mathrm{P} 0$, but not at other $\mathrm{P}$ levels. Brookton was somewhat more $\mathrm{P}$ efficient than Krichauff, and the latter responded more to AM fungi. This study showed that responses of wheat to AM inoculation and $\mathrm{P}$ supply were quite different from those of clover, and changed during development. Results are discussed in relation to the underlying soil properties.
\end{abstract}

\section{Introduction}

Phosphorus (P) is one of the major nutrients limiting crop production worldwide. In areas of

\footnotetext{
* FAX No: + 61-8-8303-6511

E-mail: h.li@adelaide.edu.au
}

southern Australia, such as the Eyre Peninsula, highly calcareous soils are frequently used for wheat (Triticum aestivum) production. Despite relatively high total soil $\mathrm{P}$, crops often suffer severe $\mathrm{P}$ deficiency and have low responsiveness to the application of granular $\mathrm{P}$ fertilisers such as monoammonium phosphate (Holloway et al., 
2001). Most soils on the Eyre Peninsula have a high P-adsorption capacity, dominated by Cabound P. Colwell (1963) P exceeds published values of the critical concentration $\left(21 \mathrm{mg} \mathrm{kg}^{-1}\right)$ required for wheat grown in the South Australian wheat belt (Reuter et al., 1995), but is a poor predictor of available $\mathrm{P}$ determined from plant growth, because bicarbonate releases $P$ from this soil that is not plant-available (Bertrand et al., 2003). Efforts are being made to improve the effectiveness of fertiliser application in such difficult soils (Holloway et al., 2001, 2004), but little attention has been given to the interactions between arbuscular mycorrhizal (AM) fungi and cereal crops. However, colonisation of wheat by indigenous AM fungi in one soil from the Eyre Peninsula at $8 \mathrm{wk}$ under controlled conditions was up to $76 \%$ ( $\mathrm{Li}$ et al., unpublished), suggesting that AM fungi may play a considerable role in the soil biological systems, including plant nutrition.

AM fungi are widespread in soils and form symbiotic (and frequently mutualistic) associations with many plant species. Colonisation often increases plant growth by improving $\mathrm{P}$ uptake, particularly on P-deficient soils (Smith and Read, 1997). However, there is increasing recognition that plant responses vary from positive to negative along a mutualism-parasitism continuum (Johnson et al., 1997) and that growth depressions are frequently attributed to high carbon demands of the fungi, that are not offset by increased nutrient uptake (e.g. Graham and Abbott, 2000 and references therein). It is widely believed that wheat is unlikely to benefit from AM colonisation (Ryan and Graham, 2002). It has a relatively large, finely branched root system with dense root hairs and many reports suggest that it is poorly colonised, with values ranging between 10 and $30 \%$ of root length. Wheat also may show growth depressions in response to AM colonisation, at least during vegetative development (Graham and Abbott 2000; Zhu et al., 2001a). In contrast, other studies indicate that wheat can be highly colonised by AM fungi (up to $80 \%$ ) under controlled conditions and in the field (Khan, 1975; Dodd and Jeffries, 1989; Hetrick et al., 1993), although the degree of colonisation does not correlate with plant growth. The mycorrhizal pathway of $\mathrm{P}$ uptake has been shown to deliver considerable amounts of $\mathrm{P}$ to wheat, regardless of growth response (Ravnskov and Jakobsen, 1995; Schweiger and Jakobsen, 1999; Yao et al., 2001) and positive effects of AM colonisation on $\mathrm{P}$ uptake, growth and/or yield of wheat have been reported both in controlled environment and field experiments (Khan, 1975; Al-Karaki and Al-Omoush, 2002; Mohammad et al., 2004). These contrasting findings highlight the uncertainties with respect to development and function of AM symbioses in wheat. Discrepancies may stem from use of different cultivars, variations in extent of colonisation or aggressiveness of the AM fungi (which would impose different carbon demands on the plants), evaluation of effects at different stages of vegetative or reproductive development and from differences in $\mathrm{P}$ availability.

The aim of this study was to evaluate the potential role of AM fungi in the growth of wheat in soil from the Eyre Peninsula, South Australia and to try to unravel the potentially complex interactions with $\mathrm{P}$ fertilisation. In one experiment spring wheat (cv. Brookton) was compared with clover (Trifolium subterraneum L.), which is highly responsive to AM in other soil types (e.g. Facelli et al., 1999). The second experiment examined the effects of AM colonisation on vegetative growth and yield of two spring wheat cultivars (Brookton and Krichauff), with four levels of soil $\mathrm{P}$ supply at two harvests. Previous studies have shown that wheat production in this soil remained low despite the high levels of $P$ supply $(100 \mathrm{~kg} P$ $\mathrm{ha}^{-1}$ added as superphosphate) (Wilhelm and Growden, 1999). Clover also grows poorly and is not included in rotations in the area. Our preliminary experiment demonstrated that the resin $\mathrm{P}$ was low and increased slowly with increasing application of $\mathrm{P}$ (also see Materials and methods). Therefore, $\mathrm{P}$ application in this study was higher $\left(130-390 \mathrm{~kg} \quad \mathrm{P} \mathrm{ha}^{-1}\right)$ than normal field application, in order to increase plant-available $\mathrm{P}$ and achieve an acceptable growth rate of wheat. Krichauff is a variety commonly grown in southern Australia, and has been shown to be colonised $(>40 \%)$ by AM fungi associated with growth depressions during vegetative growth (Zhu and Smith, 2001; Zhu et al., 2001a). Cultivar Brookton has higher $\mathrm{P}$ uptake efficiency than Krichauff (Zhu et al., 2001b). 


\section{Materials and methods}

The soil was collected from Cungena, Eyre Peninsula, South Australia. It is a highly calcareous grey sandy loam, and classified as a Calcixerollic Xerochrept in the Soil Taxonomy System (Soil Survey Staff, 1994). It is considered to be highly $\mathrm{P}$ deficient on the basis of plant growth, despite high values of total and Colwell-extractable $\mathrm{P}$ (see Introduction). Two extraction methods: anion exchange resin strips (McLaughlin et al., 1994) and bicarbonate extraction (Colwell, 1963) were used to estimate the available $\mathrm{P}$. The soil had a $\mathrm{pH}$ of $8.0(0.01 \mathrm{M} \mathrm{CaCl})$ and contained $5 \mathrm{mg} \mathrm{kg}^{-1}$ resin $\mathrm{P}$ or $34 \mathrm{mg} \mathrm{kg}^{-1}$ Colwell $\mathrm{P}$, $320 \mathrm{mg} \mathrm{kg}^{-1}$ total $\mathrm{P}, 35.5 \% \mathrm{CaCO}_{3}$ and $0.86 \%$ organic carbon. It was air-dried, passed through a $2 \mathrm{~mm}$ sieve and autoclaved at $121^{\circ} \mathrm{C}$ for $1 \mathrm{~h}$ twice over a $3 \mathrm{~d}$ period to eliminate indigenous AM fungi. Two experiments were conducted in the same glasshouse and with the same harvesting procedures and analysis of soil and tissue, but with different soil and sand mixture, soil volume per plant, growth season and nutrient addition.

Experiment 1. Vegetative responses of wheat and clover to four AM fungi with and without additional $P$

The experiment had a complete factorial design with two $\mathrm{P}$ levels, five inoculation treatments (four AM fungi and non-inoculated), two plant species (clover and wheat) and one harvest. Two $\mathrm{P}$ levels were established: no additional P (P0) and with $\mathrm{CaHPO}_{4}$ added to give $100 \mathrm{mg}$ additional $\mathrm{P} \mathrm{kg}^{-1}$ soil (P100), mixed thoroughly with the soil before potting. This addition gave extracted $\mathrm{P}$ values of $24 \mathrm{mg} \mathrm{kg}^{-1}$ resin $\mathrm{P}$ or $118 \mathrm{mg} \mathrm{kg}^{-1}$ Colwell P. Arbuscular mycorrhizal (AM) treatments received $10 \%(\mathrm{w} / \mathrm{w})$ of dry pot culture material of Glomus coronatum Giovannetti (WUM 16), G. etunicatum Becker and Gerdemann (UT 316A-1), G. mosseae (Nicol. and Gerd.) Gerdemann and Trappe (NBR 41) or G. intraradices Schenck and Smith (DAOM 181602), grown on Allium porrum L. The inoculum consisted of colonised root fragments and soil containing spores and external hyphae of the AM fungi. Sterile soil/sand mix, as was used for the inoculum culture, was added to the nonmycorrhizal (NM) pots. This control treatment had no significant effect on clover growth compared with addition of 'inoculum' from NM pot culture (Li et al., unpublished). Experiments with several AM and NM plant species, including grasses, show that this control does not result in overestimation of AM responses (e.g. Koide and Li, 1989; Smith and Smith, 1981; Wilson et al., 1988).

Wheat (Triticum aestivum L. cv. Brookton) and clover (Trifolium subterraneum L. cv. Mt. Barker) were used. Seeds were surface-sterilised in $3 \%$ sodium hypochlorite solution for $10 \mathrm{~min}$, rinsed with reverse osmosis ( $\mathrm{RO})$ water and germinated on moist paper for $2 \mathrm{~d}$. Germinated seeds of clover were coated with a suspension of Rhizobium leguminosarum biovar trifolii prior to planting. Three seedlings were sown in each pot containing $420 \mathrm{~g}$ of soil and thinned to two per pot after emergence. Soil water content was adjusted to $13.5 \%(\mathrm{w} / \mathrm{w})$ by regularly watering with RO water, taking into account increases in plant fresh weight during the experiment. Nutrients were supplemented by adding $5 \mathrm{~mL}$ modified Long Ashton solution minus $\mathrm{P}$ weekly (total $30 \mathrm{~mL}$ $\left.\operatorname{pot}^{-1}\right)$. These additions supplied nutrients for wheat with $\left(\mathrm{mg} \mathrm{kg}^{-1}\right) \mathrm{K}_{2} \mathrm{SO}_{4}, 25 ; \mathrm{CaCl}_{2} \cdot 2 \mathrm{H}_{2} \mathrm{O}$, 31; $\mathrm{MgSO}_{4} \cdot 7 \mathrm{H}_{2} \mathrm{O}, 26 ; \mathrm{CuSO}_{4} \cdot 5 \mathrm{H}_{2} \mathrm{O}, 0.01$; $\mathrm{ZnSO}_{4} \cdot 7 \mathrm{H}_{2} \mathrm{O}, 0.02 ; \mathrm{MnCl}_{2} \cdot 4 \mathrm{H}_{2} \mathrm{O}, 0.13 ; \mathrm{Na}_{2-}$ $\mathrm{MoO}_{4} \cdot 2 \mathrm{H}_{2} \mathrm{O}, 0.002 ; \mathrm{H}_{3} \mathrm{BO}_{3}, 0.2 ;$ Fe EDTA, 2.6; $\left(\mathrm{NH}_{4}\right)_{2} \mathrm{SO}_{4}, 38$ and $\mathrm{NaNO}_{3}, 49$. The same amount of nutrient solution, but without $\left(\mathrm{NH}_{4}\right)_{2} \mathrm{SO}_{4}$ and $\mathrm{NaNO}_{3}$, was added for clover. The pots were arranged randomly on one bench in the glasshouse and were rearranged when watered. The experiment was conducted from September to October 2002 with natural light and a diurnal temperature range between 16 and $22^{\circ} \mathrm{C}$. Wheat and clover were harvested at 6 and $8 \mathrm{wk}$ after emergence, respectively.

Experiment 2. Growth responses of two wheat cultivars to Glomus intraradices at early and mature stages of development with different soil $P$ supply

The experiment had a complete factorial design with four P levels, two wheat cultivars, two inoculation treatments and two harvests. Soil was 
mixed with sand in the ratio $70: 30(\mathrm{w} / \mathrm{w})$. A preliminary test had shown that this mixture reduced bicarbonate-extractable $\mathrm{P}$, and was also easier to separate from roots. The mixture had a $\mathrm{pH}$ of $8.0\left(0.01 \mathrm{M} \mathrm{CaCl}_{2}\right)$. Nutrients were thoroughly incorporated into the mixture at the following rates (mg kg${ }^{-1}$ dry mix): $\mathrm{K}_{2} \mathrm{SO}_{4}, 174$; $\mathrm{CaCl}_{2} \cdot 2 \mathrm{H}_{2} \mathrm{O}, 75 ; \mathrm{MgSO}_{4} \cdot 7 \mathrm{H}_{2} \mathrm{O}, 45 ; \mathrm{CuSO}_{4}$. $5 \mathrm{H}_{2} \mathrm{O}, 2.1 ; \mathrm{ZnSO}_{4} \cdot 7 \mathrm{H}_{2} \mathrm{O}, 5.4 ; \mathrm{MnSO}_{4} \cdot 7 \mathrm{H}_{2} \mathrm{O}$, 10.5; $\mathrm{CoSO}_{4} \cdot 7 \mathrm{H}_{2} \mathrm{O}, 0.39 ; \mathrm{Na}_{2} \mathrm{MoO}_{4} \cdot 2 \mathrm{H}_{2} \mathrm{O}, 0.18$; $\mathrm{H}_{3} \mathrm{BO}_{3}, 0.3$; Fe EDTA, 0.4. Nitrogen was added as $\mathrm{NH}_{4} \mathrm{NO}_{3}$ at $0.1 \mathrm{~g} \mathrm{~N} \mathrm{~kg}^{-1}$ at the start of experiment, and was supplemented by adding $0.05 \mathrm{~g}$ $\mathrm{N} \mathrm{kg}^{-1}$ several times during the growth period ( 3 additions for plants harvested at $6 \mathrm{wk}, 3$ more additions for plants harvested at $19 \mathrm{wk}$ ).

Two wheat cultivars, Brookton and Krichauff, were used. Four surface-sterilised and germinated seeds were transplanted to each pot filled with $1 \mathrm{~kg}$ of the growth medium. Seedlings were thinned to one per pot after emergence. The AM fungus was $G$. intraradices and inoculum was applied as for Experiment 1. Phosphorus was added as $\mathrm{CaHPO}_{4}$ to give four levels: 0, 50, 100 and $150 \mathrm{mg}$ additional $\mathrm{P}$ per $\mathrm{kg}$ soil. These treatments are referred to as $\mathrm{P} 0, \mathrm{P} 50, \mathrm{P} 100$ and $\mathrm{P} 150$ respectively. They produced resin $\mathrm{P} /$ Colwell $\mathrm{P}$ of $4 / 24,10 / 61,21 / 113$ and $23 / 143 \mathrm{mg} \mathrm{P} \mathrm{kg}{ }^{-1}$ respectively. There were 4 replicates for each treatment. Soil was brought to a water content of $12.5 \%(\mathrm{w} / \mathrm{w})$ at the start of the experiment and maintained as far as possible close to this value by regular watering with $\mathrm{RO}$ water, adjusting the weight of water added to take into account plant growth. The experiment was conducted from April to August 2003 in the glasshouse and plants were harvested at $6 \mathrm{wk}$ (vegetative stage) and 19 wk (maturity).

\section{Plant harvest and analysis}

Plants were thoroughly washed with RO water and separated into roots and shoots. Root subsamples of known weight were cleared and stained using a modification of the method of Phillips and Hayman (1970), omitting phenol from the reagents. The percentage of root length colonised (\% RLC) was determined by the method of Giovannetti and Mosse (1980). Subsamples of plants were digested with $70 \%$ nitric acid and analysed by the phosphovanado-molydate method (Hanson, 1950) for P in shoots and roots, and by Inductively Coupled Plasma Atomic Emission Spectroscopy (ICP-AES) for $\mathrm{P}$ and $\mathrm{Zn}$ in grain of wheat.

\section{Data analysis}

Data are presented as means and standard errors of means of three (Experiment 1) or four (Experiment 2) replicates. Data were analysed using GenStat Release 6.1, Lawes Agricultural Trust (Rothamsted Experimental Station, UK). Treatment effects were detected by two-way ANOVA and means were compared by $\operatorname{LSD}_{0.05}$. Differences between the two wheat cultivars in Experiment 2 were tested by a two-sample paired $t$ test.

\section{Results}

Experiment 1. Vegetative responses of wheat and clover to four AM fungi with and without additional $P$

\section{AM colonisation}

No AM fungal colonisation occurred in uninoculated plants (results not shown). All AM plants became colonised, although the \% RLC of wheat was relatively low $(6-17 \%)$, compared with clover (8-52\%; Figure $1 \mathrm{a}$ and $\mathrm{b})$. Addition of $\mathrm{P}$ (P100) did not affect colonisation of wheat by G. coronatum, but decreased \% RLC by the other three AM fungi $(P<0.001)$. Colonisation of clover varied greatly with different AM fungi $(P<0.001)$, with the highest \% RLC for G. intraradices at $\mathrm{P} 0$. At $\mathrm{P} 100$ colonisation in clover showed small decreases with $G$. intraradices and G. mosseae, and increases with G. coronatum and G. etunicatum.

\section{Plant growth}

The growth of both plants in the soil without additional P supply was slow; wheat showed poor tillering and clover remained small. However, non-mycorrhizal (NM) wheat grew relatively well at P0 (compared to clover) and showed a very small positive response to $\mathrm{P}$ addition (Figure 2a). NM clover grew poorly and did not respond at all to $\mathrm{P}$ addition (Figure $2 \mathrm{~b}$ ). The 

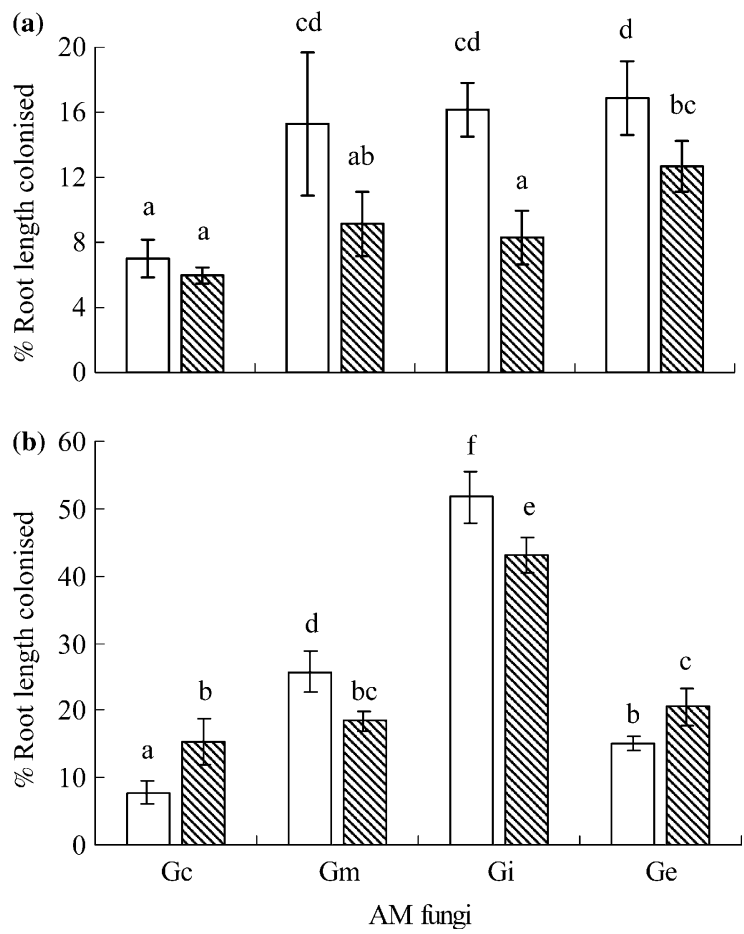

Figure 1. Percent root length colonised by G. coronatum, G. mosseae, G. intraradices, and G. etunicatum (Gc, Gm, Gi and Ge respectively) in wheat (a) and clover (b), grown in P0 (white bars) and P100 (diagonally hatched bars) soil in Experiment 1. Bars are means of three replicates \pm SEM. Bars with the same letters are not significantly different at $P<0.05$.

effect of AM colonisation on the growth of the two plants differed with different AM fungi and soil P supply. There was a significant interaction between AM fungi and soil $\mathrm{P}$ supply on wheat growth $(P<0.05)$. AM colonisation by $G$. coronatum and $G$. mosseae decreased the $\mathrm{DW}$ of wheat at $\mathrm{P} 0$. However, at $\mathrm{P} 100$, G. mosseae, G. intraradices and G. etunicatum gave small positive responses. In contrast, at P0 clover growth was greatly increased by inoculation with $G$. mosseae, $G$. intraradices and $G$. etunicatum $(P<0.001)$. Application of $\mathrm{P}$ had significant additional effects on DW of AM clover with G. coronatum and G. etunicatum.

\section{P uptake}

Increased $\mathrm{P}$ supply significantly increased $\mathrm{P}$ concentrations in shoots of both AM and NM wheat $(P<0.001$; Figure 3a). At P0 G. coronatum and $G$. mosseae increased $\mathrm{P}$ concentrations and at P100 all the fungi did so. Application of P did not increase shoot $\mathrm{P}$ concentrations of NM clover, but did so in AM plants colonised by G. coronatum, G. mosseae and G. intraradices at both $\mathrm{P}$ levels $(P<0.001$; Figure $3 \mathrm{~b})$. Total $\mathrm{P}$ uptake in wheat (the product of DW and $\mathrm{P}$ concentration) was greatly increased by additional $\mathrm{P}$ both in AM and NM plants $(P<0.001$, results not shown). AM fungi did not increase total $\mathrm{P}$ uptake of wheat at $\mathrm{P} 0$, but did so markedly at P100. In clover P uptake by NM plants was very low, regardless of $\mathrm{P}$ addition, and was increased by AM fungal colonisation at both $\mathrm{P}$ levels $(P<0.001)$, with some variations with different fungi.

Experiment 2. Growth responses of two wheat cultivars to Glomus intraradices at different stages of development with different soil P supply

\section{AM colonisation}

No AM fungal colonisation was observed in uninoculated treatments (results not shown). Both wheat cultivars were well colonised at $6 \mathrm{wk}$ $(\sim 50 \%)$ by $G$. intraradices at P0 and \% RLC subsequently increased significantly up to $70 \%$ at maturity (19 wk) in all soil $\mathrm{P}$ treatments $(P<0.001) \quad$ (Figure $4 \mathrm{a}$ and b). However, 

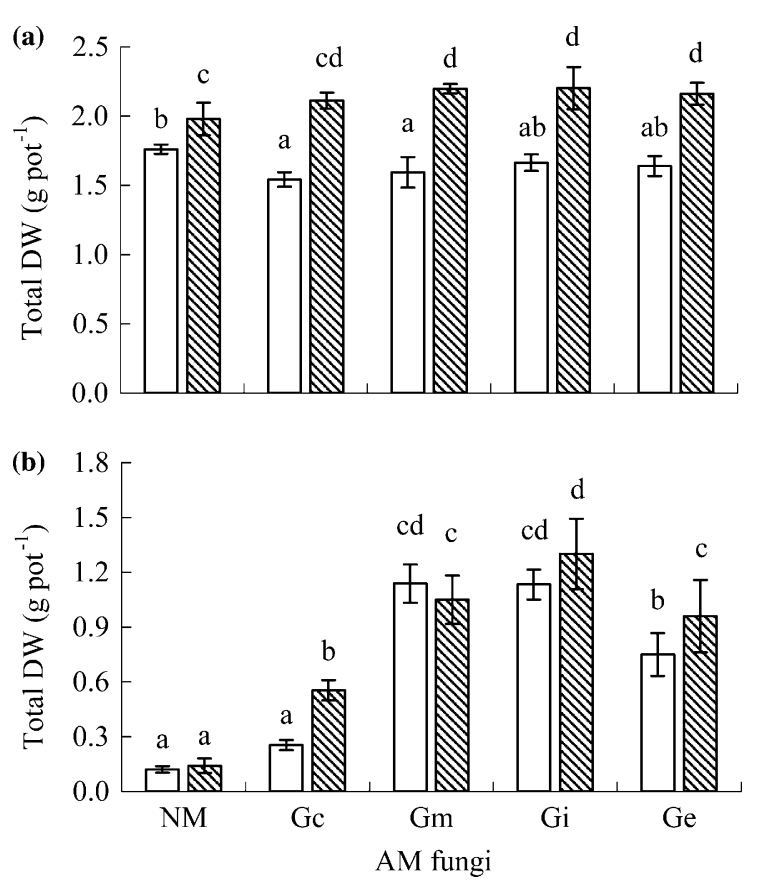

Figure 2. Total (shoot + root) DW $\left(\mathrm{g}_{\mathrm{pot}}^{-1}\right)$ of wheat (a) and clover (b) inoculated with $G$. coronatum, G. mosseae, $G$. intraradices, and G. etunicatum (Gc, Gm, Gi and $\mathrm{Ge}$ respectively), grown in P0 (white bars) and P100 (diagonally hatched bars) soil in Experiment 1. There were two plants per pot. Bars are means of three replicates \pm SEM. Bars with the same letters are not significantly different at $P<0.05$.

colonisation decreased consistently with increasing $\mathrm{P}$ addition $(P<0.001)$. There were no significant differences in \% RLC between the two cultivars when compared at the same harvest and $\mathrm{P}$ level (analysed by using a two-sample $t$ test, $P<0.05)$.

\section{Plant growth and grain yield}

For both cultivars, addition of $\mathrm{P}$ significantly increased total plant DW at both harvests and grain yield at maturity $(P<0.001)$; the highest grain yield was obtained in AM plants at P100 (Figure 5). At $6 \mathrm{wk}, G$. intraradices significantly depressed plant growth in terms of total DW at all levels of $\mathrm{P}(P<0.001$; Figure 5a). By maturity, the growth depression had disappeared except at P0 (Figure 5b). There was no significant difference between the two cultivars at $6 \mathrm{wk}$, but at 19 wk NM plants of Brookton were significantly greater than Krichauff at both P50 and P100 $(P<0.05)$. Brookton had significantly higher grain yields than Krichauff in all treatments
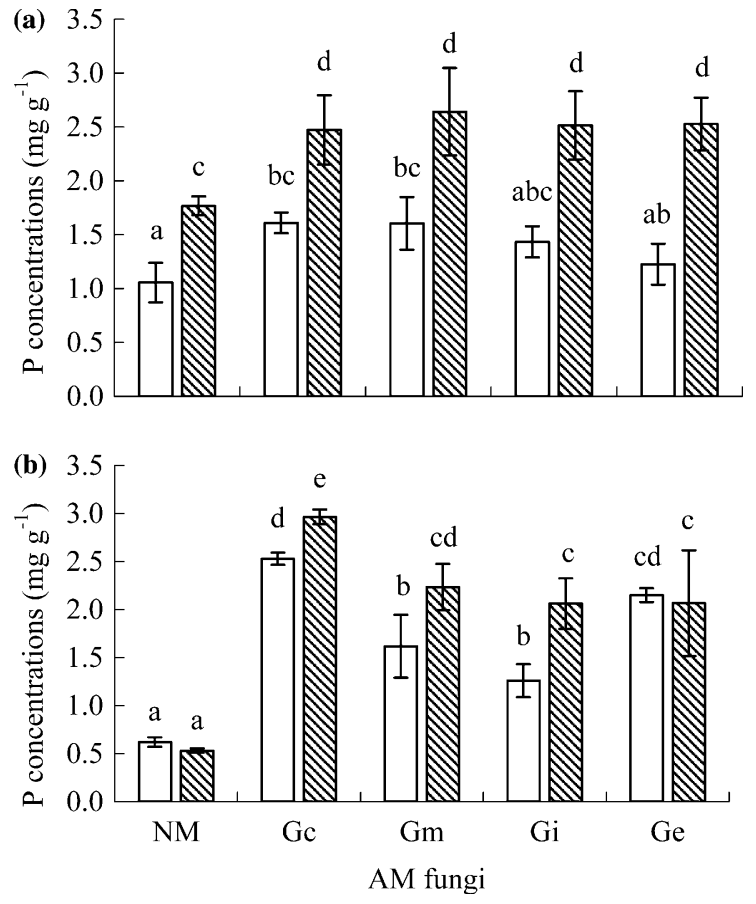

Figure 3. P concentrations in shoots of wheat (a) and clover (b) inoculated with G. coronatum, G. mosseae, G. intraradices, and $G$. etunicatum (Gc, Gm, Gi and Ge respectively), grown in P0 (white bars) and P100 (diagonally hatched bars) soil in Experiment 1. Bars are means of three replicates \pm SEM. Bars with the same letters are not significantly different at $P<0.05$.

(AM and NM) with high P supply (> P50) (Figure 5c). Grain yield was also significantly affected by both AM colonisation and soil $\mathrm{P}$ for both cultivars and there was a significant interaction between the two factors $(P<0.001)$ : AM $<\mathrm{NM}$ at $\mathrm{P} 0, \mathrm{AM}=\mathrm{NM}$ at $\mathrm{P} 50$ and $\mathrm{AM}>\mathrm{NM}$ at $\mathrm{P} 100$ and P150. Addition of P from P50 to P100 increased the yield of both AM and NM Brookton, but further $\mathrm{P}$ addition had no effect. In contrast, yield of NM Krichauff did not respond to $\mathrm{P}$ addition between $\mathrm{P} 50$ and $\mathrm{P} 150$, but there was a response to $\mathrm{P}$ in AM plants at both $\mathrm{P} 50$ and $\mathrm{P}$ 100 .

\section{Phosphorus uptake}

Shoot $\mathrm{P}$ concentrations ranged from 1.6 to $3.8 \mathrm{mg} \mathrm{g}^{-1}$ at $6 \mathrm{wk}$ and declined markedly between 6 and $19 \mathrm{wk}$, at which time values ranged from 0.2 to $0.9 \mathrm{mg} \mathrm{g}^{-1}$ (Figure $6 \mathrm{a}$ and b). Addition of $\mathrm{P}$ significantly enhanced shoot $\mathrm{P}$ concentrations at $6 \mathrm{wk}(P<0.001)$, but not always at $19 \mathrm{wk}$, with no differences between the two 

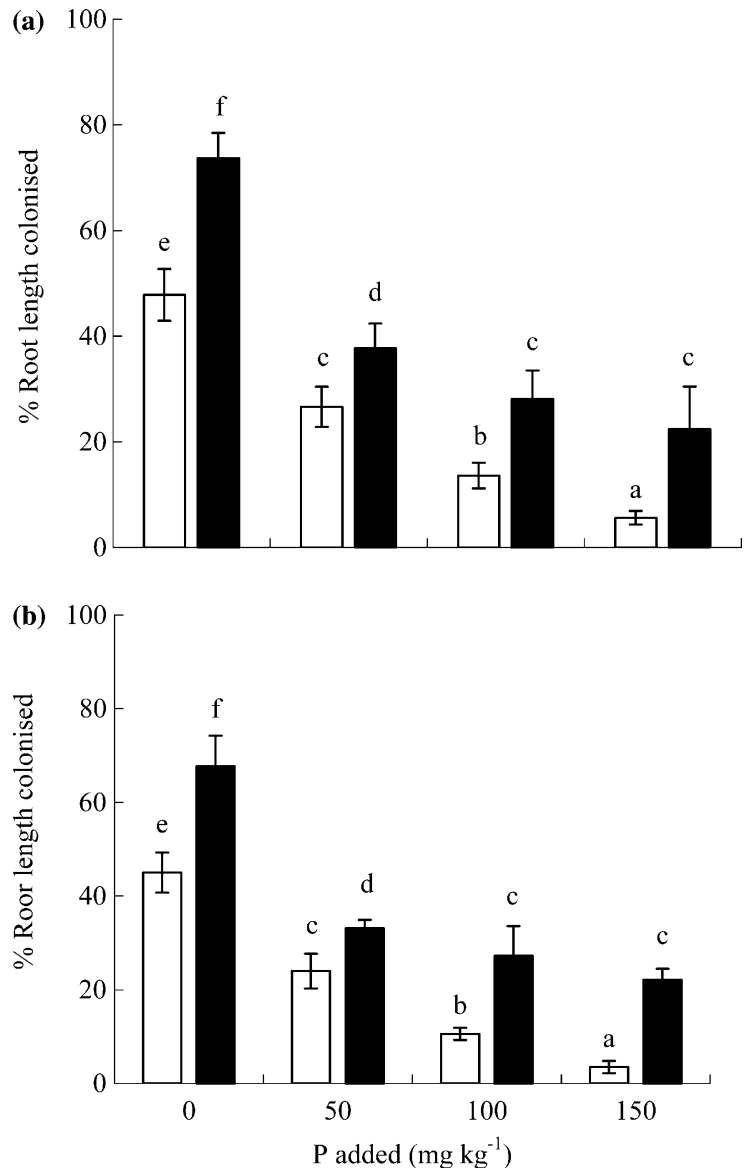

Figure 4. Percent root length colonised by $G$. intraradices at $6 \mathrm{wk}$ (white bars) and 19 wk (black bars) of two wheat cultivar Brookton (a) and Krichauff (b), grown with different soil $\mathrm{P}$ supply in Experiment 2. Bars are means of four replicates \pm SEM. Bars with the same letters are not significantly different at $P<0.05$.

cultivars at either harvest except at $6 \mathrm{wk}$ at P150 (Brookton $>$ Krichauff). Shoot $\mathrm{P}$ concentrations were generally not significantly affected by AM colonisation at either harvest, but $\mathrm{AM}$ roots at $\mathrm{P} 0$ had higher $\mathrm{P}$ concentrations than NM roots, especially at 6 wk $\left(\sim 0.7 \mathrm{mg} \mathrm{g}^{-1}\right.$ and $\sim 1.3 \mathrm{mg} \mathrm{g}^{-1}$ in $\mathrm{NM}$ and $\mathrm{AM}$ roots respectively: results not shown).

The grain $\mathrm{P}$ concentrations $\left(1.9-4.8 \mathrm{mg} \mathrm{g}^{-1}\right)$ were much higher than concentrations in shoots (Figure 6c). They significantly increased with increased $\mathrm{P}$ supply in $\mathrm{NM}$ and $\mathrm{AM}$ plants $(P<0.001)$, with small differences between the two cultivars. AM fungal colonisation only increased $\mathrm{P}$ concentration in grain at $\mathrm{P} 0$ (both cultivars); with higher $\mathrm{P}$ supply, $\mathrm{P}$ concentrations in
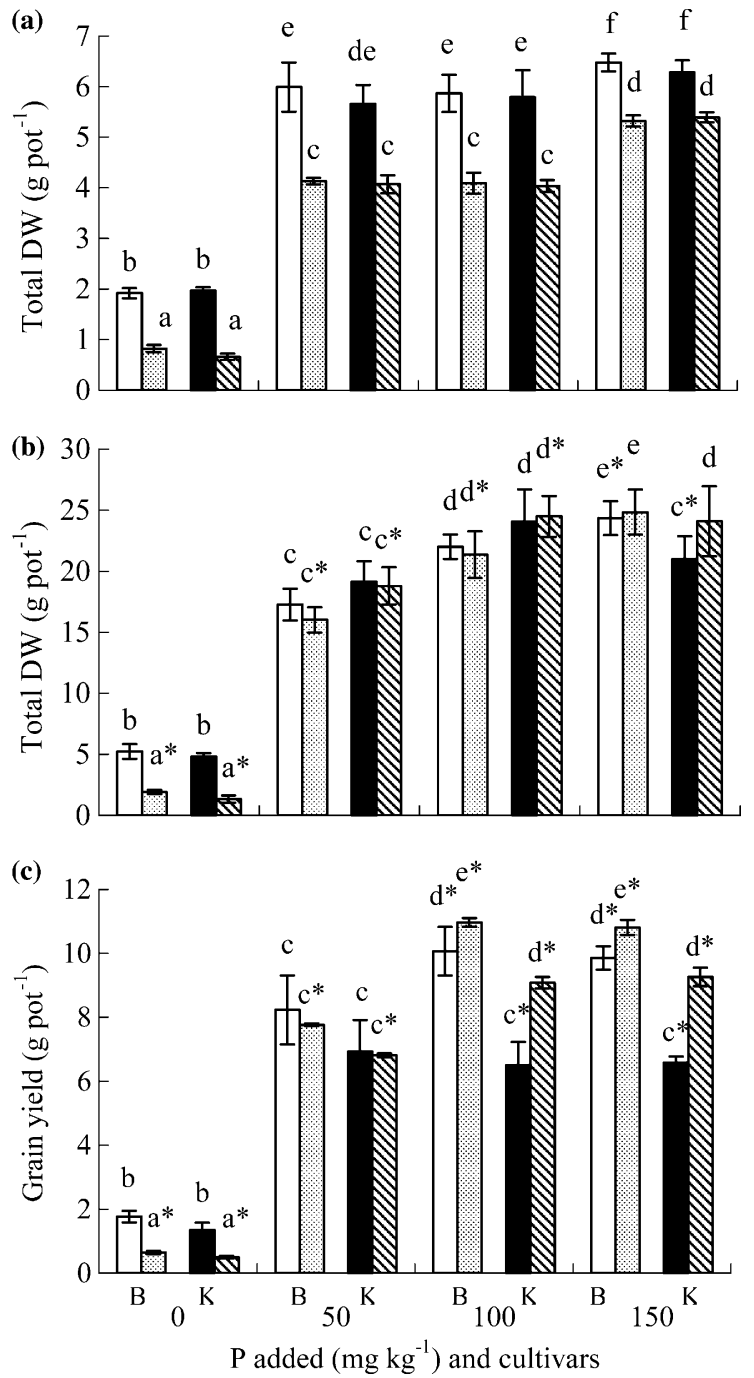

Figure 5. Total DW (shoot + root) at $6 \mathrm{wk}$ (a) and (shoot + root + head) at $19 \mathrm{wk}$ (b) and grain yield (c) of two wheat cultivars grown with different soil $\mathrm{P}$ supply in Experiment 2. Brookton (B): non-mycorrhizal (white bars) and mycorrhizal (stippled bars); Krichauff $(\mathrm{K})$ : non-mycorrhizal (black bars) and mycorrhizal (diagonally hatched bars). There was one plant per pot. Bars are means of four replicates \pm SEM. Bars with the same letters are not significantly different at $P<0.05$. Significant differences by $t$ test (two-sample paired) between two cultivars at the same soil $\mathrm{P}$ and mycorrhizal treatment at $P<0.05$ shown by '*'.

grain were similar in AM and NM plants (except Krichauff at P100, where $\mathrm{AM}<\mathrm{NM}$ ). At $\mathrm{P} 0$ grain $\mathrm{Zn}$ concentrations were significantly higher $(P<0.001, t$ test $)$ in AM plants $\left(60 \mathrm{mg} \mathrm{kg}^{-1}\right)$ than in NM $\left(50 \mathrm{mg} \mathrm{kg}^{-1}\right)$ with no difference between the two cultivars. However, such 

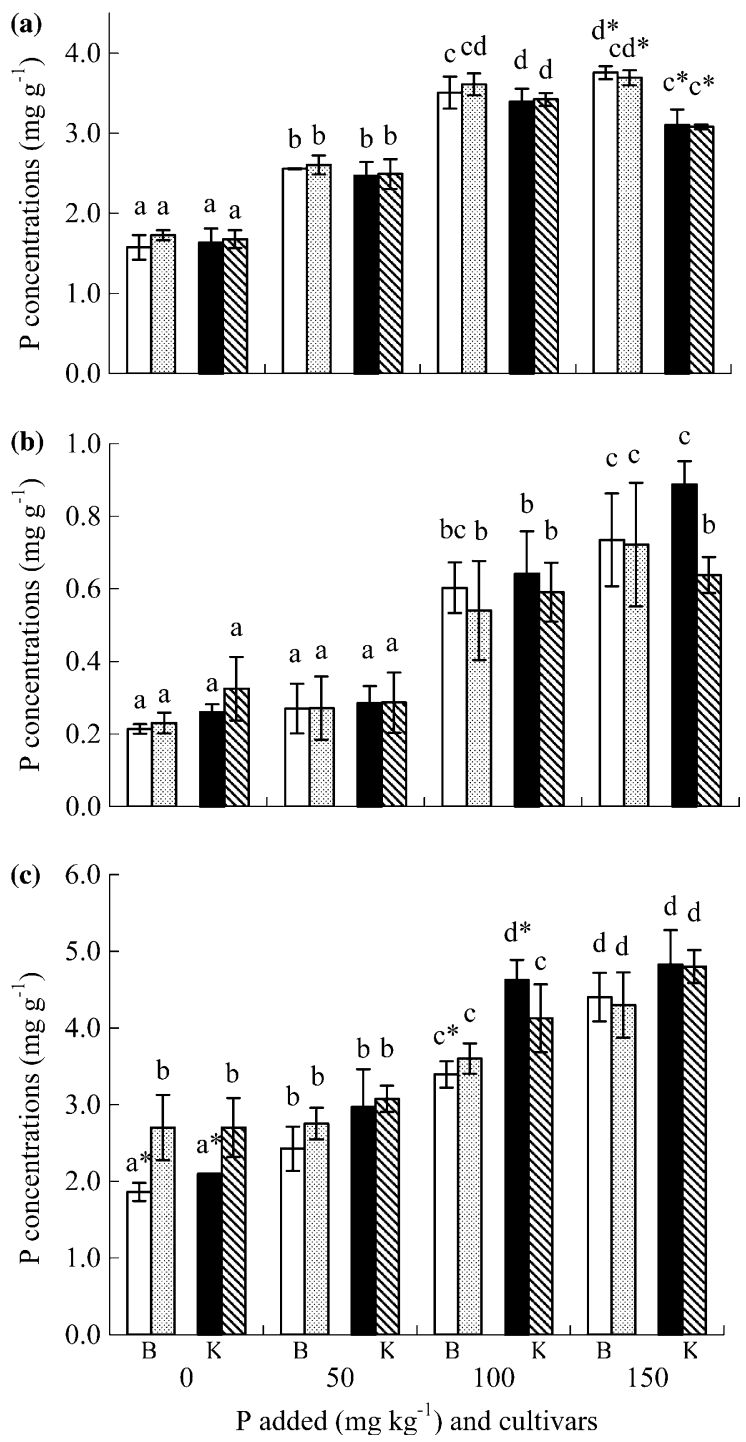

Figure 6. Shoot $\mathrm{P}$ concentrations at 6 (a) and $19 \mathrm{wk}$ (b) and grain $\mathrm{P}$ concentrations (c) of two wheat cultivars grown with different soil $\mathrm{P}$ supply in Experiment 2. Brookton (B): nonmycorrhizal (white bars) and mycorrhizal (stippled bars); Krichauff (K): non-mycorrhizal (black bars) and mycorrhizal (diagonally hatched bars). Bars are means of four replicates \pm SEM. Bars with the same letters are not significantly different at $P<0.05$. Significant differences by $t$ test (two-sample paired) between two cultivars at the same soil $\mathrm{P}$ and mycorrhizal treatment at $P<0.05$ shown by '*'.

differences were not observed at higher $\mathrm{P}$ supply (results not shown).

The total $\mathrm{P}$ uptake $\left(\mathrm{mg} \mathrm{pot}^{-1}\right.$, results not shown) in vegetative parts was much higher at $6 \mathrm{wk}$ than $19 \mathrm{wk}$. Addition of $\mathrm{P}$ increased vegetative $\mathrm{P}$ contents at both harvests and grain $\mathrm{P}$ contents in $\mathrm{AM}$ and $\mathrm{NM}$ plants $(P<0.001)$. AM colonisation decreased total vegetative $P$ contents at all soil $\mathrm{P}$ levels at $6 \mathrm{wk}$, and in treatments with $>50 \mathrm{mg} \mathrm{kg}^{-1}$ at $19 \mathrm{wk}$ (except Brookton at P150). Grain P contents were markedly increased by colonisation at P100 for both cultivars and P 150 for Krichauff.

\section{Discussion}

In both experiments, NM plants without additional $\mathrm{P}$ grew poorly. Wheat was able to produce up to about $2 \mathrm{~g}$ DW per pot and clover only about $0.1 \mathrm{~g}$. The shoot $\mathrm{P}$ concentrations of all wheat plants in Experiment 1 and both NM and AM plants at $6 \mathrm{wk}$ at low $\mathrm{P}$ supply $(<\mathrm{P} 50)$ in Experiment 2 were less than $2.6 \mathrm{mg} \mathrm{g}^{-1}$. This is much lower than the critical concentrations determined for wheat grown under controlled condition (3.5-4.6 $\mathrm{mg} \mathrm{g}^{-1}$, Elliott et al., 1997). The shoot $\mathrm{P}$ concentrations of $\mathrm{NM}$ clover in Experiment 1 ranged $0.53-0.62 \mathrm{mg} \mathrm{g}^{-1}$, which was also lower than critical $\mathrm{P}$ concentrations (2.6-6.0 $\mathrm{mg} \mathrm{g}^{-1}$, Bolland, 1994). These results indicate that the growth of these plants was limited by $\mathrm{P}$, confirming that the soil is deficient in plant-available P (Holloway et al., 2001). In Experiment 1 wheat responded slightly to additional $\mathrm{P}$ when NM but clover not at all, showing that there is limited potential for benefits from conventional fertilisation. In the absence of AM fungi, clover could not access soil P effectively, but wheat could use a small proportion of the $P$ fertiliser, which can partly be attributed to a more extensive and finer root system and exudation of organic acids by wheat (Zhu et al., 2001b). Values for Colwell $P$ were high (34 and $24 \mathrm{mg} \mathrm{kg}^{-1}$ in the unamended soil and soil/sand mix, respectively) compared with those for resin $\mathrm{P}$ (5 and $4 \mathrm{mg} \mathrm{kg}^{-1}$, respectively). Our results showing poor growth and $\mathrm{P}$ uptake in unamended soils confirm the inadequacy of Colwell $\mathrm{P}$ as a predictor of plant-available $\mathrm{P}$ for both plant species grown in this soil. Increasing the $P$ supply increased both Colwell and resin $\mathrm{P}$, with percentage increases in resin $\mathrm{P}$ either very similar to or somewhat higher than Colwell $\mathrm{P}$ depending on $\mathrm{P}$ application. The ratios of resin $\mathrm{P}$ to Colwell $\mathrm{P}$ in soil and soil/sand mix were very similar 
( 0.15 and 0.17 at $\mathrm{P} 0$ and 0.20 and 0.19 at $\mathrm{P} 100$, for the two growth media, respectively). It can be concluded that resin $\mathrm{P}$ provides a better measure of plant-available $\mathrm{P}$ in this soil (in agreement with Bertrand et al., 2003) and that the soil/sand mix, which provided advantages in terms of a lower initial Colwell $\mathrm{P}$ value and easier harvesting, was a reasonable surrogate for complete soil. Given the low plant-available $\mathrm{P}$, responses of plants to AM colonisation might be expected. The poor growth responses of clover to $\mathrm{P}$ supply may seem surprising, but similar results showing that clover ( $T$. repens and $T$. pratense) does not respond to extra $\mathrm{P}$ have been obtained previously in soil with high $\mathrm{pH}(>7)$ (Mosse et al., 1976; $\mathrm{Li}$ et al., 1991). The growth of clover may have been limited by poor nodulation and hence $\mathrm{N}$ supply. However, in a separate experiment to check this, addition of up to $100 \mathrm{mg} \mathrm{N} \mathrm{kg}{ }^{-1}$ soil to clover did not improve growth in this soil $(\mathrm{Li}$ et al., unpublished), so this explanation is unlikely.

Inoculated plants became colonised by AM fungi in both experiments, with the extent influenced by plant-fungus combination, soil $\mathrm{P}$ status, harvesting time and soil volume explored by the individual plant. In Experiment 1, wheat (cv Brookton) had lower \% RLC than clover, which could be due to the earlier harvest date for wheat. However, the trend is in agreement with previous findings of relatively low colonisation in wheat, consistent with root morphology and rates of root growth (Hall, 1975; Parke and Kaeppler, 2000). In contrast, in Experiment 2 both wheat cultivars were highly colonised by $G$. intraradices at an early stage of development to levels that were slightly lower than the same cultivars grown in non-sterilised soil from the field site $(\sim 76 \%, \mathrm{Li}$ et al., unpublished). Thus in this experiment inoculation achieved realistic levels of colonisation, which continued to increase during the growth period and could have imposed carbon costs on the plants, particularly during early growth stages, as shown for wheat colonised by 'aggressive' fungi (Graham and Abbott, 2000). The influence of $\mathrm{P}$ in reducing colonisation markedly in wheat and less so (or not at all) in clover is again consistent with previous work (Oliver et al., 1983; Graham and Abbott, 2000; Al-Karaki and Al-Omoush, 2002). The different colonisation rates of wheat in the two experiments (Experiment
$1<$ Experiment 2) can probably be explained by the differences in experimental conditions, particularly the soil volume explored by individual plants. Decreasing soil volume per plant significantly decreases colonisation (Baath and Hayman, 1984; Koide, 1991).

Colonisation produced positive growth responses in clover at $8 \mathrm{wk}$ regardless of $\mathrm{P}$ supply and was accompanied by increases in $\mathrm{P}$ concentrations and hence total $\mathrm{P}$ uptake. These results agree with the high responsiveness of clover species observed many times previously and provide an important comparison with wheat grown in this highly P-fixing soil (Smith et al., 1979; Facelli et al., 1999). In Experiment 2, Brookton had higher yield and total $\mathrm{P}$ uptake, but lower $\mathrm{P}$ concentration in the grain than Krichauff, in agreement with previous work on the relative efficiencies of these two cultivars ( $\mathrm{Zhu}$ et al., 2001b). The growth response of wheat to AM fungi was strongly influenced by soil P level and changed during development. Wheat generally responded negatively to AM colonisation during the early stages of growth (6 wk in both experiments). By $19 \mathrm{wk}$ (Experiment 2) vegetative growth in AM and NM plants of both wheat cultivars was similar when $\mathrm{P}$ was added, but at $\mathrm{P} 0$, where a marked negative growth response persisted. Moreover, the effect of colonisation on grain yield also changed with soil $\mathrm{P}$ supply; yield was lower in AM plants than in NM plants at P0, similar at P50 and higher at both P100 and P150. Krichauff showed lower yields but greater mycorrhizal yield responses than Brookton. It appears that in Krichauff AM fungi improved the use efficiency of P applied at P100 and P150. At the vegetative stage, although there was a weak positive response to $\mathrm{AM}$ fungi at P100 in Experiment 1, this did not occur in Experiment 2. This difference between the two experiments may partly result from the different rates of colonisation and hence differences in associated $\mathrm{C}$ drains by the fungi. Overall AM fungi only contributed positively to growth and $\mathrm{P}$ uptake of wheat when resin $\mathrm{P}$ was $\sim 20 \mathrm{mg} \mathrm{kg}^{-1}$ and when \% RLC was moderate to low. This finding emphasizes the importance of a balance between the capacity of the fungi to increase $\mathrm{P}$ uptake and their carbon demand.

Our observation of ontogenetic changes in mycorrhizal response and their sensitivity to $\mathrm{P}$ 
supply may partially explain the contradictory reports of mycorrhizal responses of wheat in the past (see Introduction), as most previous experiments have been conducted with only one harvest during vegetative growth, or several harvests over a relatively short growth period or limited range of $\mathrm{P}$ applications (Baon et al., 1992; Graham and Abbott, 2000; Zhu et al., 2001a). Positive mycorrhizal responses at intermediate soil P levels have, however, been reported in wheat (Al-Karaki and Clark, 1999; Al-Karaki and Al-Omoush, 2002). In our experiments the benefits of AM fungi for wheat yield occurred at high rates of soil $\mathrm{P}$ supply with relatively low $\%$ RLC. This may partly result from the properties of this high P-fixing soil, in which high application of $\mathrm{P}$ is required to achieve a moderate level of plant-available $\mathrm{P}$, measured by resin extraction. Furthermore, contrary to the widely held belief, high positive responses of plants to AM fungi are not necessarily related to high \% RLC (e.g. Hetrick et al., 1992; Smith et al., 2004), especially where the latter may impose a significant $\mathrm{C}$ demand.

In agreement with our findings, growth depressions in wheat associated with colonisation by AM fungi have been mostly reported at vegetative stages (Baon et al., 1992; Graham and Abbott, 2000; Zhu et al., 2001a; Ryan and Graham, 2002). There have also been reports of positive effects on growth and $\mathrm{P}$ uptake at maturity (Al-Karaki and Al-Omoush, 2002; Mohammad et al., 2004). Effects of AM fungi on vegetative growth of wheat that were different from the effects on grain yield have been shown previously in field experiments (Khan, 1975; Mohammad et al., 1998). Our results show clear differences in reallocation of resources from vegetative to reproductive organs in wheat, with AM plants being more efficient than NM. Similar results have been obtained for tomato, pepper and oats (Dodd et al., 1983; Koide et al., 1988; Bryla and Koide, 1990). In general terms, reallocation of $\mathrm{P}$ from vegetative to reproductive structures is clearly demonstrated by the marked reductions in $\mathrm{P}$ concentration in shoots between 6 and 19 wk. In addition, our results show two different effects on allocation to grain. At P0 there were negative effects of AM on grain weight in both cultivars, whereas grain $\mathrm{P}$ and $\mathrm{Zn}$ concentrations were higher in AM plants. With higher $\mathrm{P}$ supply, yield of AM plants was increased over NM plants, but $\mathrm{P}$ contents were reduced in vegetative parts and there were no concomitant increases in concentrations of other nutrients. Thus, despite the fact that there was a carbon drain to the AM fungi in low $\mathrm{P}$ soil, resulting in poor vegetative growth and low grain weight per plant, the colonisation by AM fungi still maintained individual grain quality by enhancing grain $\mathrm{P}$ and $\mathrm{Zn}$ concentrations and hence increased offspring vigor (Koide and $\mathrm{Lu}$, 1992). The increased $P$ allocated to grain could have partly come from the AM roots, which had almost twice the P concentration of NM roots at $6 \mathrm{wk}$, but much lower concentrations (and differences between AM and NM plants) at maturity. With higher $\mathrm{P}$ application, growth was generally greater and mycorrhizal colonisation lower, so that $\mathrm{C}$ allocation to grain kept pace with $\mathrm{P}$ allocation and no increases in $\mathrm{P}$ (or indeed $\mathrm{Zn}$ ) concentrations were observed, although yield was increased.

Low AM colonisation, growth depressions and absence of increases in $\mathrm{P}$ uptake in vegetative tissues have given the widespread impression that AM fungi have no benefit to wheat grown in low $\mathrm{P}$ soil. Our results emphasize that this is not the case, particularly in the highly P-fixing soil used in this experiment, in which application of moderate to high amounts of $\mathrm{P}$ was required for the beneficial effects of AM on yield to be apparent. These benefits are likely to be the consequence of operation of the mycorrhizal $\mathrm{P}$ uptake pathway, under conditions of low to moderate $\mathrm{C}$ drain to the AM fungi (see also Graham and Abbott, 2000). Use of radioactive $\mathrm{P}$ and compartmented pots has shown that this pathway contributes significantly to $\mathrm{P}$ uptake in wheat (Ravnskov and Jakobsen, 1995; Schweiger and Jakobsen, 1999; Yao et al., 2001). Under conditions where no net increases in $\mathrm{P}$ uptake occur, this implies reduced uptake via root epidermis and root hairs (see Smith et al., 2003, 2004).

\section{Conclusions}

Growth depression in AM wheat in a highly calcareous, P-fixing soil was overcome by addition of moderate amounts of $\mathrm{P}$, resulting in significant 
increases in grain yield in AM plants. Under the same conditions, clover ( $T$. subterraneum), a species with high AM responsiveness, grew poorly and showed no response to added $\mathrm{P}$, probably reflecting higher $\mathrm{P}$ demand, or possibly limitation by other nutrients.

\section{Acknowledgements}

We thank Debbie Miller and Colin Rivers for technical support. We are also grateful to Dr. Robert Holloway and Dr. Neil Howes (South Australia Research and Development Institute) who provided soil and wheat seeds, respectively. HY. Li is grateful for an International Postgraduate Research Scholarship from the University Adelaide. Her research is part of the project No. K2CX2-413-06, CAS in China.

\section{References}

Al-Karaki G N and Al-Omoush M 2002 Wheat response to phosphogypsum and mycorrhizal fungi in alkaline soil. J. Plant Nutr. 25, 873-883.

Al-Karaki G N and Clark R B 1999 Mycorrhizal influence on protein and lipid of durum wheat grown at different soil phosphorus levels. Mycorrhiza. 9, 97-101.

Baath E and Hayman D S 1984 Effect of soil volume and plant density on mycorrhizal infection and growth response. Plant Soil 77, 373-376.

Baon J B, Smith S E, Alston A M and Wheeler R D 1992 Phosphorus efficiency of three cereals as related to indigenous mycorrhizal infection. Aust. J. Agric. Res. 43, 479-491.

Bertrand I, Holloway R E, Armstrong R D and McLaughlin M J, 2003 Chemical characteristics of phosphorus in alkaline soils from southern Australia. Aust. J. Agric. Res. 41, 61-76.

Bolland M D A 1994 Critical phosphorus concentrations for burr medic, yellow serradella, subterranean clover, and wheat. Commun. Soil Sci. Plant Anal. 25, 385-394.

Bryla D R and Koide R T 1990 Regulation of reproduction in wild and cultivated Lycopersicon esculentum Mill. by vesicular-arbuscular mycorrhizal infection. Oecologia 84, 74-81.

Colwell J D 1963 The estimation of the phosphorus fertilizer requirements of wheat in southern New South Wales. Aust. J. Exp. Agric. Anim. Husbandry 3, 190-197.

Dodd J C and Jeffries P 1989 Effect of fungicides on three vesicular-arbuscular mycorrhizal fungi associated with winter wheat (Triticum aestivum L.). Biol. Fertil. Soils 7, 120128

Dodd J C, Krikun J and Haas J 1983 Relative effectiveness of indigenous populations of vesicular-arbuscular mycorrhizal fungi from four sites in the Negev. Isr. J. Bot. 32, 10-21.

Elliott D E, Reuter D J, Reddy G D and Abbott L K 1997 Phosphorus nutrition of spring wheat (Triticum aestivum L.) $2^{*}$. Distribution of phosphorus in glasshouse-grown wheat and the diagnosis of phosphorus deficiency by plant analysis. Aust. J. Agric. Res. 48, 869-881.

Facelli E, Facelli J M, Smith S E and McLaughlin M J 1999 Interactive effects of arbuscular mycorrhizal symbiosis, intraspecific competition and resource availability on Trifolium subterraneum cv. Mt. Barker. New Phytol. 141, 535547.

Giovannetti M and Mosse B 1980 An evaluation of techniques for measuring vesicular-arbuscular mycorrhizal infection in roots. New Phytol. 84, 489-500.

Graham J H and Abbott L K 2000 Wheat responses to aggressive and non-aggressive arbuscular mycorrhizal fungi. Plant Soil 220, 207-218.

Hall I R 1975 Endomycorrhizas of Metrosideros umbellata and Weinmannia racemosa. N.Z. J. Bot. 13, 463-472.

Hanson W C 1950 The photometric determination of phosphorus in fertilizers using the phosphovanado-molybdate complex. J. Sci. Food Agric. 1, 172-173.

Hetrick B A D, Wilson G W T and Cox T S 1993 Mycorrhizal dependence of modern wheat varieties, landraces, and ancestors. Can. J. Bot. 70, 2032-2040.

Holloway R E, Bertrand I, Frischke A J, Brace D M, McLaughlin M J and Shepperd W 2001 Improving fertiliser efficiency on calcareous and alkaline soils with fluid sources of P, N and Zn. Plant Soil 236, 209-219.

Holloway R E, Frischke B M, Frischke A J, Brace D M, McLaughlin M J, Lombi E and Armstrong R D 2004 Field evidence for efficiency of fluid fertilisers. In First Australian Fluid Fertiliser Workshop, Adelaide, Australia.

Johnson N C, Graham J H and Smith F A 1997 Functioning of mycorrhizal associations along the mutualism-parasitism continuum. New Phytol. 135, 575-586.

Khan A G 1975 The effect of vesicular-arbuscular mycorrhizal associations on growth of cereals. II. Effects on wheat growth. Ann. Appl. Biol. 80, 27-36.

Koide R T 1991 Density-dependent response to mycorrhizal infection in Abutilon theophrasti Medic. Oecologia 85, 389395.

Koide R and Li M 1989 Appropriate controls for vesiculararbuscular mycorrhiza research. New Phytol. 111, 35-44.

Koide R T, Li M G, Lewis J D and Irby C 1988 Role of mycorrhizal infection in the growth and reproduction of wild. Vs. cultivated plants 1 . Wild vs cultivated oats. Oecologia 77, 537-542.

Koide R T and Lu X H 1992 Mycorrhizal infection of wild oats maternal effects on offspring growth and reproduction. Oecologia 90, 218-226.

Li X L, George E and Marschner H 1991 Extension of the phosphorus depletion zone in VA-mycorrhizal white clover in a calcareous soil. Plant Soil 136, 41-48.

McLaughlin M J, Lancaster P A, Sale P G, Uren N C and Peverill K I 1994 Comparison of cation/anion exchange resin methods for multi-element testing of acidic soils. Aust. J. Soil Res. 32, 229-240.

Mohammad A, Mitra B and Khan A G 2004 Effects of shearedroot inoculum of Glomus intraradices on wheat grown at different phosphorus levels in the field. Agric. Ecosys. Envrion 103, 245-249.

Mohammad M J, Pan W L and Kennedy A C 1998 Seasonal mycorrhizal colonization of winter wheat and its effect on wheat growth under dryland field conditions. Mycorrhiza 8, 139-144.

Mosse B, Powell C L and Hayman D S 1976 Plant growth responses to vesicular-arbuscular mycorrhiza. IX. 
Interactions between VA mycorrhiza, rock phosphate and symbiotic nitrogen fixation. New Phytol 76, 331-342.

Oliver A J, Smith S E, Nicholas D J D, Wallace W and Smith F A 1983 Activity of nitrate reductase in Trifolium subterraneum: effects of mycorrhizal infection and phosphate nutrition. New Phytol 94, 63-79.

Parke J L and Kaeppler S W 2000 Effects of genetic differences among crop species and cultivars upon the arbuscular mycorrhizal symbiosis. In Arbuscular Mycorrhizas: Physiology and Function. Ed. D D J Douds. pp. 131-146. Kluwer Academic Publishers, Dordrecht, The Netherlands.

Phillips J M and Hayman D S 1970 Improved procedures for clearing roots and staining parasitic and vesicular-arbuscular mycorrhizal fungi for rapid assessment of infection. Trans. Br. Mycol. Soc. 55, 158-161.

Ravnskov S and Jakobsen I 1995 Functional compatibility in arbuscular mycorrhizas measured as hyphal $\mathrm{P}$ transport to the plant. New Phytol. 129, 611-618.

Reuter D J, Dyson C B, Elliott D E, Lewis D C and Rudd C L 1995 An appraisal of soil phosphorous testing data for crops and pastures in South Australia. Aust. J. of Exp. Agric. 35, 979-995.

Ryan M H and Graham J H 2002 Is there a role for arbuscular mycorrhizal fungi in production agriculture? Plant Soil 244, 263-271.

Schweiger P F and Jakobsen I 1999 Direct measurement of arbuscular mycorrhizal phosphorus uptake into field-grown winter wheat. Agron. J. 91, 998-1002.

Smith S E, Nicholas D J D and Smith F A 1979 Effect of early mycorrhizal infection on nodulation and nitrogen fixation in Trifolium subterraneum L. Aust. J. Plant Physiol. 6, 305-316.

Smith S E and Read D J 1997 Mycorrhizal Symbiosis. Academic Press Ltd, San Diego and London, 605 pp.

Smith F A and Smith S E 1981 Mycorrhizal infection and growth of Trifolium subterraneum: use of sterilized soil as a control treatment. New Phytol. 88, 299-309.
Smith S E, Smith F A and Jakobsen I 2004 Functional diversity in arbuscular mycorrhizal (AM) symbioses: the contribution of the mycorrhizal $\mathrm{P}$ uptake pathway is not correlated with mycorrhizal responses in growth or total $\mathrm{P}$ uptake. New Phytol. 162, 511-524.

Smith S E, Smith F A and Jakobsen I 2003 Mycorrhizal fungi can dominate phosphate supply to plants irrespective of growth responses. Plant Physiol 133, 16-20.

Soil Survey Staff 1994 Keys to soil taxonomy. United States Department of Agriculture, Soil Conservation Service, Washington, D.C.

Wilhelm N and Growden B, 1999 Phosphorus fertilisation for field crops in difficult soils. In 91st Annual Meeting of the American Society of Agronomy, Salt Lake City, Utah, USA.

Wilson G W T, Daniels Hetrick B A and Gerschefske Kitt D 1988 Suppression of mycorrhizal growth response of big bluestem by non-sterile soil. Mycologia 80, 338-343.

Yao Q, Li X L, Feng G and Christie P 2001 Influence of extramatrical hyphae on mycorrhizal dependency of wheat genotypes. Commun. Soil Sci. Plant Anal. 32, 3307-3317.

Zhu Y G and Smith S E 2001 Seed phosphorus (P) content affects growth, and $\mathrm{P}$ uptake of wheat plants and their association with arbuscular mycorrhizal (AM) fungi. Plant Soil 231, 105-112.

Zhu Y G, Smith S E, Barritt A R and Smith F A 2001a Phosphorus (P) efficiencies and mycorrhizal responsiveness of old and modern wheat cultivars. Plant Soil 237, 249255.

Zhu Y G, Smith S E and Smith F A 2001b Plant growth and cation composition of two cultivars of spring wheat (Triticum aestivum $\mathrm{L}$.) differing in $\mathrm{P}$ uptake efficiency. J. Exp. Bot. 52, 1277-1282.

Section editor: H. Lambers 